\title{
PEMBELAJARAN TEKS CERITA IMAJINASI BERBASIS HOTS (HIGHER ORDER THINKING SKILL) DENGAN MODEL DISCOVERY LEARNING
}

\author{
HOTS (HIGHER ORDER THINKING SKILL) \\ BASED IMAGINATION STORY LEARNING \\ WITH DISCOVERY LEARNING MODEL
}

\author{
Sakila \\ Sekolah Menengah Pertama Negeri 2 Singkawang \\ Ponsel: 089644235402, Pos-el: sakilaspd@yahoo.co.id
}

Diterima: 28 September 2019; Direvisi: 4 Desember 2019; Disetujui: 4 Desember 2019

DOI https://doi.org/10.26499/mab.v13i2.264

\begin{abstract}
Abstrak
Salah satu materi pembelajaran yang diamanatkan pada kurikulum 2013 di kelas VII adalah tentang teks cerita imajinasi. Tujuan penulisan ini agar pembaca mendapatkan gambaran tentang bagaimana langkah-langkah model discovery learning diterapkan dalam proses pembelajaran pada materi teks cerita imajinasi. Metode penulisan pada tinjauan ilmiah ini menggunakan metode deskriptif. Proses pengumpulan data dilakukan dengan metode studi kepustakaan. Rumusan masalah yang terdapat pada tulisan ini adalah bagaimana langkah-langkah penerapan model discovery learning dalam pembelajaran pada materi teks cerita imajinasi. Dalam pelaksanaan strategi pembelajaran berbasis HOTS yang dilakukan oleh pendidik, maka pembelajaran akan menjadi lebih efektif karena peserta didik dihadapkan pada suatu permasalahan dan akan dilatih untuk mampu memecahkan masalah tersebut. Untuk mendapatkan hasil belajar siswa yang lebih baik tentunya diperlukan strategi dan teknik yang tepat. Salah satu teknik yang digunakan adalah model discovery learning dalam pembelajaran. Upaya yang dilakukan oleh pendidik dengan model pembelajaran yang sesuai dan tepat diharapkan dapat meningkatkan hasil serta motivasi belajar peserta didik dalam pembelajaran. Berdasarkan analisis data dapat disimpulkan bahwa dengan menggunakan langkah-langkah model discovery learning secara tepat peserta didik dapat meningkatkan hasil belajar dalam pembelajaran teks cerita imajinasi.
\end{abstract}

Kata-kata kunci: cerita imajinasi; model pembelajaran; discovery learning

\begin{abstract}
One of the learning materials mandated in the 2013 curriculum in class VII is about the imagination story text. The purpose of this writing is for the reader to get a picture of how the steps of the discovery learning model are applied in the learning process in the imagination text material. The writing method in this scientific review uses a descriptive method. The process of collecting data is done by library research methods. The formulation of the problem contained in this paper is how the steps in applying the discovery learning model in learning the text material of the imagination story. In implementing HOTS-based learning strategies carried out by educators, learning will be more effective because students are faced with a problem and will be trained to be able to solve the problem. To get better student learning outcomes, of course, the right strategies and techniques are needed. One technique used is the discovery learning model in learning. Efforts made by educators with appropriate and appropriate learning models are expected to improve student learning outcomes and motivation in learning. Based on data analysis, it can be concluded that by using the steps of the discovery learning model appropriately, students can improve learning outcomes in the learning of imagination story text. Keywords: imagination stories; learning models; discovery learning
\end{abstract}




\section{Pendahuluan}

Pendidikan pada abad 21 berorientasi pada paradigma keterampilan berpikir tingkat tinggi yang dalam bahasa Inggris disebut "higher-order thinking skills" (HOTS). Pendapat ini sejalan dengan yang disampaikan Widaningsih (2019:143) bahwa pembelajaran abad 21 merupakan agenda atau fokus dalam pelaksanaan kurikulum 2013. Pada Kurikulum 2013, pembelajaran abad 21 diharapkan dapat diimplementasikan. Senada dengan hal tersebut, Widaningsih (2019:143-144) mengemukakan bahwa pada pembelajaran abad 21, terdapat empat hal yang harus disikapi secara kritis yaitu: 1) kemampuan untuk berpikir kritis (critical thinking skill); 2) kreativitas (creativity); (3) komunikasi (communication); dan 4) kolaborasi (collaboration). Lebih lanjut Rohmadi (2018:27) mengemukakan bahwa diperlukan strategi dan inovasi pembelajaran bahasa dan sastra Indonesia yang dapat menjawab tantangan zaman di abad ke-21 dengan formula 4C, yaitu critical thingking, creativity, communication, dan collaboration.

Menghadapi situasi dan kondisi sebagaimana tersebut di atas, peran pendidik di satuan pendidikan sangat besar dan sangat menentukan dalam proses pembelajaran untuk melahirkan insan pendidikan yang cerdas dan bermartabat. Hal tersebut sebagaimana yang dikemukakan Ayu (2018:1) bahwa dengan diterapkannya kurikulum 2013, seorang pendidik harus mempunyai strategi yang jitu dalam melaksanakan pembelajaran. Lebih lanjut menurutnya bahwa dalam implementasi kurikulum 2013 pendidik harus mampu berinovasi dalam menerapkan model, metode, dan strategi pembelajaran yang tentunya harus sesuai dengan situasi dan kondisi di lapangan. Di samping itu, muatan materi dan peserta didik juga perlu diperhatikan sehingga pada akhirnya kemampuan nalar peserta didik dapat dikembangkan. Senada dengan pendapat tersebut, Widaningsih mengatakan bahwa (2019:142) kurikulum dan sistem pendidikan yang baik akan menjadi siasia jika pendidik yang menjalankannya tidak berkualitas baik. Apabila proses belajar mengajar dikelola oleh pendidik yang profesional, sistem dan kurikulum yang kurang baik akan berubah menjadi baik. Hal ini menunjukkan kepada kita bahwa secanggih apapun teknologi tidak dapat menggantikan eksistensi dan peran pendidik. Keberadaan media, sarana, alat, dan teknologi hanyalah sebagai alat 
penunjang keberhasilan dalam proses pembelajaran di satuan pendidikan.

Berkaitan dengan hal tersebut, Widaningsih, (2019:9) mengemukakan bahwa di era industri 4.0, guru bahasa dan sastra Indonesia dituntut mampu membimbing peserta didik agar memiliki keterampilan yang dibutuhkan oleh revolusi industri 4.0. Kemampuan yang dimiliki adalah kemampuan teknis, kreativitas, dan pemecahan masalah yang inovatif. Dalam proses pembelajaran yang menuntut kreativitas seorang pendidik, diperlukan suatu model yang akan dipergunakan oleh seorang pendidik. Pengertian model pembelajaran adalah sebagai prosedur untuk mencapai tujuan dari sebuah proses pembelajaran. Pemberlakuan Kurikulum 2013 dapat dilaksanakan dengan tiga jenis model dalam pembelajaran. Ketiga model pembelajaran tersebut terdari atas 1) Model Pembelajaran Berbasis Proyek (Project-Based Learning) 2) Model Pembelajaran Berbasis Masalah (Problem- Based Learning); dan 3) Model Pembelajaran Berbasis Penemuan (Discovery Learning).

Dalam proses pembelajaran, pelaksanaan ketiga model tersebut di atas sesuai dengan pendekatan saintifik. Pendapat tersebut senada dengan yang dikemukakan oleh Malawi, dkk (2019:92) bahwa pada pembelajaran tematik terpadu perlu diperhatikan dan dipertimbangkan apa yang dinamakan pendekatan, strategi, model, dan metode pembelajaran. Istilah pendekatan mempunyai arti sebagai titik tolak atau sudut pandang kita terhadap proses pembelajaran. Istilah strategi mempunyai makna sebagai suatu seni menggunakan kecakapan dan sumber daya untuk mencapai sasarannya melalui hubungan yang efektif dengan lingkungan dalam situasi dan kondisi yang paling menguntungkan. Selanjutnya istilah model pembelajaran dapat diartikan sebagai sebuah rencana atau pola yang dapat digunakan untuk membentuk kurikulum, merancang bahan-bahan pengajaran, dan membimbing pengajaran. Istilah metode dapat diartikan penjabaran dari pendekatan yang diterapkan dalam proses pembelajaran. Dengan demikian, satu pendekatan dapat dijabarkan ke dalam berbagai metode sedangkan metode adalah prosedur pembelajaran yang difokuskan pada pencapaian tujuan.

Pada materi pembelajaran tentang teks cerita fantasi pada jenjang sekolah menengah pertama kelas VII semester I terdapat kompetensi dasar dan indikator sebagaimana terlihat pada tabel berikut ini. 


\begin{tabular}{|c|c|}
\hline Kompetensi Dasar & Indikator \\
\hline $\begin{array}{l}\text { 3.3. Mengidentifikasi } \\
\text { unsur-unsur teks } \\
\text { narasi (cerita } \\
\text { imajinasi) yang } \\
\text { dibaca dan } \\
\text { didengar. }\end{array}$ & 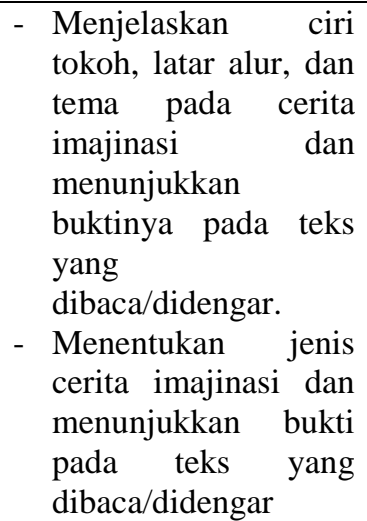 \\
\hline $\begin{array}{l}\text { 4.3. Menceritakan } \\
\text { kembali isi teks } \\
\text { narasi (cerita } \\
\text { imajinasi) yang } \\
\text { didengar dan } \\
\text { dibaca secara } \\
\text { lisan, tulis dan } \\
\text { visual. }\end{array}$ & 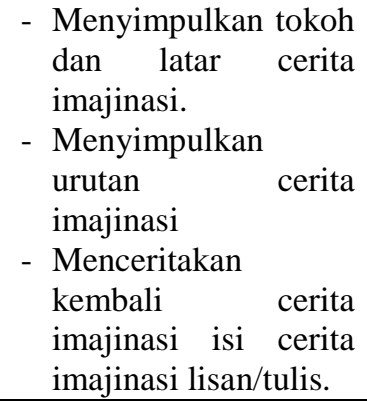 \\
\hline
\end{tabular}

Berdasarkan pengalaman penulis sebagai guru pada proses pembelajaran mata pelajaran bahasa Indonesia di kelas VII, sering ditemukan permasalahan yang terkait dengan kreativitas dan motivasi belajar peserta didik yang masih di bawah nilai kriteria ketuntasan minimal (KKM). Berdasarkan beberapa hasil studi pendahuluan yang dilaksanakan di kelas, diperoleh kenyataan bahwa kemampuan peserta didik dalam memahami teks cerita fantasi atau imajinasi masih kurang memenuhi tuntutan KKM. Hal tersebut terihat dari nilai rata-rata siswa sebesar 50. Selain itu, diperoleh fakta bahwa pertama, peserta didik belum mampu memberikan penjelasan tentang ciri tokoh, latar, alur, dan tema pada cerita fantasi; kedua peserta didik masih bingung dan belum mampu untuk menentukan jenis cerita fantasi serta menunjukkan bukti pada teks yang dibaca atau didengar.

Karena itu, guru dituntut untuk selalu berinovasi serta harus mempunyai kemampuan dalam mendesain serta mengaplikasikan sebuah model pembelajaran yang menunjang proses pembelajaran di kelas. Namun, perlu diingat bahwa model yang dipergunakan hendaknya disesuaikan dengan tema dan kompetensi dasar. Hal yang terpenting dan patut dipertimbangkan adalah penggunaannya disesuaikan dengan situasi dan kondisi siswa di kelas. Selanjutnya, hal yang terpenting adalah seorang pendidik harus dapat berinovasi dan mengelola kelas. Dalam hal ini, pendidik harus menguasai langkahlangkah dalam proses pembelajaran.

Dari berbagai masalah tersebut di atas, penulis mencoba menggunakan model atau pendekatan yang kreatif, unik, menarik, efektif, serta efisien bagi siswa. Berdasarkan pertimbangan tersebut, penulis berusaha untuk memberikan sebuah alternatif penggunaan model pembelajaran yang kreatif dan inovatif dengan memanfaatkan fasilitas yang ada. 
Salah satu model pembelajaran yang disarankan untuk mendukung proses pembelajaran adalah model discovery learning. Model ini dapat menjadi sebuah alternatif untuk model pada pembelajaran teks imajinasi (cerita fantasi). Penggunaan model pembelajaran discovery learning dilakukan agar siswa dapat memahami dengan mudah materi pembelajaran teks cerita imajinasi. Penggunaan model discovery learning merupakan penggunaan sebuah model pembelajaran yang tidak asing bagi peserta didik. Hal ini disebabkan pada dasarnya siswa sudah terbiasa melaksanakan kegiatan penemuan melalui kegiatan yang dilaksanakan sehari-hari. Hal yang terpenting adalah bahwa strategi ini diharapkan dapat memberikan output berupa peningkatan hasil belajar siswa.

Sehubungan dengan paparan di atas, penulis akan mendeskripsikan pelaksanaan model discovery learning sebagai upaya menjawab urgensi atas pengembangan HOTS dalam pembelajaran teks cerita fantasi yang dibaca dan didengar oleh para siswa. Penggunaan model discovery learning dikembangkan sebagai produk yang kreatif dan inovatif dan bertujuan untuk memberikan pengalaman terbaik belajar yang menyenangkan bagi peserta didik.

Rumusan masalah pada tulisan ilmiah ini adalah bagaimanakah langkahlangkah yang dilakukan oleh guru dengan menggunakan model discovery learning pada pembelajaran teks cerita imajinasi berbasis HOTS (higher order thinking skill)? Selanjutnya, disampaikan juga bahwa tujuan penulisan tinjauan ilmiah ini adalah untuk mengetahui langkahlangkah penggunaan model discovery learning pada pembelajaran teks cerita imajinasi berbasis HOTS (higher order thinking skill).

Tulisan ilmiah atau hasil penelitian yang berhubungan dengan penulisan tinjauan ilmiah ini di antaranya penelitian yang dilakukan oleh Sapari (2019). Sapari menyimpulkan bahwa terjadi peningkatan keterampilan berbicara siswa kelas VII 8 Sekolah Menengah Pertama Negeri 1 Metro pada Tahun Pelajaran 2018/2019 dengan menggunakan model discovery learning. Hal ini dapat dilihat dari perbandingan hasil penilaian pembelajaran siklus I, siklus II, dan siklus III yang mengindikasikan terjadi peningkatan hasil pada penilaian perencanaan pembelajaran, pelaksanaan pembelajaran, 
observasi pada aktivitas siswa, dan hasil belajar siswa.

Perbedaan tulisan ini dengan penelitian tersebut di atas adalah bahwa dalam tulisan ini penulis mengkaji dan memaparkan secara rinci langkah-langkah pembelajaran dengan model discovery learning pada pembelajaran teks cerita imajinasi berbasis HOTS (higher order thinking skill) sedangkan pada penelitian di atas, langkah-langkah pembelajaran dengan model tersebut tidak dijelaskan secara terperinci.

\section{Landasan Teori}

Menurut Ariani dan Aji Septiaji (2019:114), teks cerita imajinasi adalah teks yang termasuk dalam teks narasi. Teks narasi dapat diartikan sebagai sebuah teks yang mengisahkan suatu peristiwa atau kejadian. Teks imajinasi mengisahkan sebuah cerita tentang hasil rekaan dan khayalan dari seorang penulis. Cerita imajinasi dapat dikatakan juga sebagai cerita fantasi yang berbentuk karangan/tulisan untuk menggambarkan, menuturkan, atau membayangkan banyak perbuatan, pengalaman, dan kejadian (angan-angan, khayalan, imajinasi, atau rekaan belaka). Selanjutnya, Setiyaningsih dan Meita (2019:43) menyimpulkan bahwa cerita imajinasi atau fantasi adalah gambaran peristiwa sesuai urutan waktu berdasarkan daya pikir dan daya khayal yang dituangkan dalam bentuk cerita.

Unsur-unsur cerita imajinasi sebagaimana yang dikemukakan oleh Ariani dan Aji Septiaji (2019:115-116) terdiri atas (1) adanya keajaiban, keanehan, atau kemisteriusan; (2) ide cerita dan tema cerita berupa majic, supernatural atau futuristic; penggunaan berbagai latar (lintas ruang dan waktu); (4) tokoh unik (memiliki kesaktian); dan (5) bahasa yang digunakan variatif, ekspresif, dan ragam percakapan (bukan bahasa formal).

Struktur cerita imajinasi hampir sama dengan struktur teks lain, di antaranya orientasi, komplikasi, dan resolusi (Ariani dan Aji Septiaji, 2019:116). Orientasi dapat dipahami sebagai pengenalan bagian dalam cerita yang meliputi latar, tokoh, tema, dan sedikit alur kepada pembaca. Komplikasi dapat dipahami sebagai konflik atau permasalahan yang dimulai dari awal hingga puncak permasalahan. Resolusi dapat dipahami sebagai penyelesaian suatu masalah dalam cerita. Resolusi merupakan bagian penentu yang akan mengarah pada akhir cerita apakah 
berakhir dengan kebahagiaan atau kesedihan.

Cerita imajinasi memiliki ciri-ciri kebahasaan sebagai pembeda dengan teks lainnya sebagaimana yang dijelaskan Ariani dan Aji Septiaji (2019:117-118). Ciri-ciri yang dimaksud adalah

1) Penggunaan kata ganti. Misalnya aku, dia, mereka, Afiza, Delia.

2) Penggunaan kata yang berhubungan dengan panca indra untuk mendeskripsikan latar tempat, waktu, dan suasana.

3) Penggunaan pilihan kata bermakna kias dan khusus

4) Penggunaan kata sambung penanda urutan waktu

5) Penggunaan kata atau ungkapan keterkejutan.

6) Penggunaan dialog atau kalimat langsung dalam cerita.

Menurut Mariyaningsih dan Mistina (2018:66), dengan model discovery learning, proses pembelajaran yang mata pelajaran tidak disajikan dalam bentuk finalnya, namun siswa diharapkan dapat mengorganisasi sendiri. Sejalan dengan hal tersebut, menurut Budiningsih dalam Mariyaningsih dan Mistina (2018:66), pembelajaran discovery merupakan model pembelajaran di mana siswa dapat memahami konsep, arti, dan hubungan pembelajaran yang pada akhirnya menuju pada suatu akhir simpulan. Selanjutnya, Hosnan (2014:282) mengemukakan bahwa discovery learning adalah sebuah model pembelajaran yang bertujuan mengembangkan cara belajar aktif yaitu menemukan dan menyelidiki sendiri. Dengan pendekatan ini, hasil yang diperoleh akan dapat bertahan lama dalam ingatan. Dengan pendekatan ini pula, siswa dapat belajar berpikir secara analitis dan dapat memecahkan sendiri masalah yang mereka hadapi. Senada dengan pendapat tersebut, Kurniasih dkk. (2014:64) mengemukakan bahwa model discovery learning merupakan sebuah proses pembelajaran yang terjadi jika pelajaran tidak disajikan dengan pelajaran dalam bentuk finalnya. Discovery merupakan sebuah cara untuk menemukan konsep, serangkaian data, atau informasi yang diperoleh melalui pengamatan atau percobaan.

Menurut Sund dalam Suryasubrata (2002:193), discovery learning merupakan proses mental di mana peserta didik mempunyai kemampuan mengasimilasikan sesuatu konsep atau prinsip. Proses mental tersebut meliputi kegiatan mengamati, mencerna, mengerti menggolong-golongkan, membuat dugaan, menjelaskan, mengukur, 
membuat simpulan dan lain sebagainya. Sejalan dengan itu, Ruseffendi (2006:329) menjelaskan bahwa metode discovery learning merupakan sebuah metode mengajar yang mengatur pengajaran sedemikian rupa sehingga peserta didik dapat memperoleh pengetahuan yang belum diketahuinya melalui pemberitahuan, sebagian atau seluruhnya ditemukan sendiri oleh mereka.

Menurut Asmui (2009:154), metode discovery learning merupakan metode yang bertujuan untuk mengembangkan cara belajar peserta didik secara aktif dengan cara siswa menemukan dan menyelidiki sendiri sehingga hasil yang diperoleh akan bertahan lama dalam ingatan.

Konsep berpikir tingkat tinggi, menurut Ariyana dkk. (2018:5) lebih dikenal sebagai Higher Order Thinking Skill (HOTS) yang dipicu oleh empat kondisi. Adapun empat kondisi tersebut adalah sebagai berikut.

a. Sebuah situasi belajar tertentu yang memerlukan strategi pembelajaran yang spesifik dan tidak dapat digunakan pada situasi belajar lainnya.

b. Kecerdasan tidak lagi dipandang sebagai kemampuan yang tidak dapat diubah, melainkan kesatuan pengetahuan yang dipengaruhi oleh berbagai faktor yang terdiri atas lingkungan belajar, strategi, dan kesadaran dalam belajar.

c. pemahaman pandangan yang telah bergeser dari satu dimensi, linier, hirarki, atau spiral menuju pemahaman pandangan ke multi dimensi dan interaktif.

d. keterampilan berpikir tingkat tinggi yang lebih spesifik seperti penalaran, kemampuan analisis, pemecahan masalah, dan keterampilan berpikir kritis dan kreatif.

Dalam pelaksanaan strategi HOTS yang dilakukan oleh pendidik, pembelajaran akan menjadi lebih efektif karena peserta didik dihadapkan pada suatu permasalahan, tetapi siswa akan dilatih untuk mampu memecahkan masalah tersebut. Untuk mendapatkan hasil belajar yang lebih baik, tentunya diperlukan strategi dan teknik yang tepat. Salah satu teknik yang digunakan adalah penggunaan model discovery learning dalam pembelajaran.

\section{Metode Penelitian}

Penulisan tinjauan ilmiah ini termasuk penelitian pustaka. Menurut Fathoni (2006:95), penelitian pustaka merupakan penelitian yang dilakukan 
pada ruang perpustakaan yang bertujuan menghimpun serta menganalisis data yang bersumber dari perpustakaan, baik berupa buku, majalah ilmiah, kisah-kisah sejarah, dokumen-dokumen maupun materi perpustakaan lain yang dapat dijadikan rujukan dalam penulisan ilmiah. Dalam penulisan ini, penulis mengumpulkan sumber data melalui artikel-artikel yang dimuat di jurnal daring dan luring. Di samping itu, penulis mengunjungi perpustakaan sekolah untuk mendapatkan buku-buku yang membahas materi penulisan tinjauan ilmiah ini. Senada dengan pendapat di atas, Mahmud dalam Kristianto (2018:169) menjelaskan bahwa teknik kajian pustaka merupakan langkah terarah agar dunia imajinasi dalam sastra berpaut dengan dunia ilmiah yang dipaparkan oleh teori sastra.

Metode penulisan pada tulisan ilmiah ini adalah metode deskriptif. Metode deskriptif adalah metode yang cara kerjanya lebih memberikan interpretasi dan pemahaman terhadap objek yang diamati (Ratna, dalam Suhardi 2019:38). Menurut Ghony dan Almanshur dalam Suhardi (2019:38), metode dekriptif adalah metode yang cara kerjanya mendeskripsikan dan menganalisis fenomena, peristiwa, aktivitas sosial, sikap, kepercayaan, persepsi, dan pemikiran orang secara individu maupun secara kelompok. Penggunaan metode deskriptif dalam tulisan ini dimaksudkan untuk mendeskripsikan hasil identifikasi unsurunsur dan menceritakan kembali isi teks narasi (cerita imajinasi) berbasis HOTS (higher order thinking skill) dengan model pembelajaran discovery learning.

Data dalam penelitian kualitatif ini adalah kata-kata, frasa, klausa, kalimat, dan gambar-gambar. Hal ini senada dengan yang disampaikan Moleong dalam Hestiyana (2018:85) bahwa penelitian deskriptif memiliki variabel data berupa kalimat. Penggunaan beberapa data dan angka hanyalah sebagai alat mempermudah pengumpulan dan analisis data. Selanjutnya, metode pengumpulan data yang digunakan dalam penelitian ini adalah studi pustaka. Dalam hal ini, Nazir (2005:93) menyatakan bahwa dalam studi kepustakaan atau studi literatur, sumber data sekunder diperlukan untuk mengetahui sampai sejauh mana ilmu yang berhubungan dengan penelitian telah berkembang, sampai di mana simpulan dan generalisasi yang pernah dibuat sehingga situasi yang diperlukan diperoleh.

Sebelum dilakukan analisis dan penafsiran data, keabsahan data terlebih 
dahulu dilakukan. Teknik pemeriksaan keabsahan data dilakukan dengan cara trianggulasi. Trianggulasi adalah teknik pemeriksaan keabsahan data yang memanfaatkan sesuatu yang lain di luar data itu untuk keperluan pengecekan atau pembanding terhadap data itu (Moleong, 2009:330).

Analisis data dilakukan dengan mengikuti model Miles dan Huberman dalam Suhardi (2019:38) dengan langkahlangkah sebagai berikut: (1) melakukan identifikasi masalah sebagai objek penelitian; (2) melakukan reduksi data, (3) interpretasikan data yang diperoleh sesuai teori; dan (5) menyusun simpulan.

Pada tahap analisis data, penulis melakukan tahap-tahap sebagai berikut.

1) Penulis melakukan identifikasi data berdasarkan kelompoknya dan diklasifikasikan sesuai dengan kebutuhan.

2) Tahap selanjutnya, penulis melakukan reduksi data.

3) Penyajian data dengan cara mengorganisasikan informasi yang telah direduksi.

4) Menginterpretasikan data dengan merangkum dan disajikan secara terpadu sehingga fokus pada pembelajaran.
5) Tahap terakhir adalah menyusun simpulan akhir.

\section{Pembahasan}

\subsection{Pemilihan Model Discovery}

\section{Learning dalam pembelajaran}

Salah satu strategi pembelajaran yang bertujuan untuk meningkatkan keterampilan berpikir siswa adalah strategi pembelajaran berbasis HOTS (higher order thinking skill). Salah satu teknik dalam penerapan strategi HOTS adalah penggunaan model discovery learning. Model discovery learning sangat penting untuk dibahas. Hal ini disebabkan model ini dapat menjelaskan sebuah makna kegiatan yang dilakukan oleh pendidik pada saat pembelajaran berlangsung. Tentunya, guru mempunyai alasan tertentu untuk melakukan pemilihan strategi yang akan digunakan dalam proses pembelajaran. Untuk itu, dalam menggunakan metode discovery learning, pendidik dapat berperan sebagai pembimbing yang memberikan kesempatan kepada peserta didik untuk belajar secara aktif sebagaimana pendapat Sardiman, 2005:145) bahwa guru harus dapat membimbing dan mengarahkan kegiatan belajar siswa sesuai dengan tujuan. Untuk itulah, seorang pendidik dalam mengaplikasikan metode discovery 
learning hendaknya dapat memberikan kesempatan kepada peserta didik untuk belajar secara lebih mandiri. Sejalan dengan pendapat itu, Bruner dalam Budiningsih (2005:41) mengatakan bahwa proses belajar siswa dipengaruhi oleh budaya seseorang yang berpengaruh pada tingkah laku.

Model discovery learning dalam pembelajaran teks cerita imajinasi mempunyai kelebihan dan keunggulan sebagaimana dikemukakan oleh Suherman dkk (2001:179). Kelebihankelebihan model ini adalah sebagai berikut.

1) Siswa aktif dalam kegiatan belajar sebab ia berpikir dan menggunakan kemampuan untuk menemukan hasil akhir.

2) Siswa memahami benar bahan pelajarannya sebab siswa mengalami sendiri proses menemukannya. Sesuatu yang diperoleh dengan cara ini lebih lama untuk diingat.

3) Menemukan sendiri dapat menimbulkan rasa puas. Kepuasan batin ini mendorong siswa untuk melakukan penemuan lagi sehingga minat belajarnya meningkat.

4) Siswa yang memperoleh pengetahuan dengan metode penemuan akan lebih mampu mentransfer pengetahuannya ke berbagai konteks.

5) Metode ini melatih siswa untuk lebih banyak belajar sendiri.

Menurut Ariyana dkk. (2018:35-36), Berkaitan dengan pengembangan kemampuan berfikir tingkat tinggi, hal yang perlu diperhatikan dalam mengembangkan kemampuan berpikir tingkat tinggi terletak pada konten/materi pembelajaran dan konteks peserta didik. Apabila peserta didik belum siap untuk melakukan keterampilan berpikir tingkat tinggi, perlu dibangun terlebih dahulu jembatan penghubung antara proses berpikir tingkat rendah menuju berpikir tingkat tinggi. Caranya adalah dengan membangun skemata dari pengetahuan awal yang telah diperoleh sebelumnya dengan pengetahuan baru yang akan diajarkan. Setelah terpenuhi, guru perlu mempersiapkan sebuah situasi nyata yang dapat menstimulasi proses berpikir tingkat tinggi dengan menciptakan dilema, kebingungan, tantangan, dan ambiguitas dari permasalahan yang akan dihadapi peserta didik sebagaimana dikutip King, Goodson \& Rohani dalam Ariyana dkk, 2018:35-36). 


\subsection{Langkah-langkah penerapan}

Dalam rangka penerapan

Kurikulum 2013 sebagaimana dijelaskan dalam Peraturan Menteri Pendidikan dan Kebudayaan Nomor 22 Tahun 2016 tentang standar proses terdapat tiga model pembelajaran. Model pembelajaran ini diharapkan membentuk perilaku saintifik, sosial serta mengembangkan rasa keingintahuan. Adapun ketiga model tersebut, yaitu (1) Model pembelajaran melalui penyingkapan/penemuan yang lebih dikenal dengan istilah discovery/inquiry learning; (2) Model Pembelajaran Berbasis Masalah yang dikenal dengan istilah Problem-based Learning/PBL; dan (3) Model Pembelajaran Berbasis Projek atau lebih dikenal dengan istilah Project Based Learning/PJBL. Namun, guru selaku pendidik dapat juga mengembangkan pembelajaran di kelas dengan menggunakan model pembelajaran lain, seperti yang lebih dikenal dengan istilah
Cooperative Learning, seperti: Numbered Head Together (NHT), Jigsaw, Make a Match, Think-Pair-Share (TPS), Picture and Picture, Example not Example, dan lain sebagainya.

Menurut Ariyana dkk. (2018:29), langkah kerja model pembelajaran penyingkapan/penemuan (discovery learning) adalah sebagai berikut.

1) pemberian rangsangan (stimulation),

2) pernyataan/identifikasi masalah (problem statement),

3) pengumpulan data (data collection),

4) pengolahan data (data processing),

5) pembuktian (verification), dan

6) penarikan simpulan/generalisasi (generalization)..

Berdasarkan langkah kerja tersebut, discovery learning dapat dirancang oleh guru sebagaimana yang dikemukakan oleh Ariyana dkk. (2018:29--31) dengan rancangan sebagai berikut.

Tabel Langkah-langkah pembelajaran Discovery learning

\begin{tabular}{|l|l|l|}
\hline \multicolumn{1}{|c|}{ Langkah kerja } & \multicolumn{1}{|c|}{ Aktivitas Guru } & \multicolumn{1}{c|}{ Aktivitas siswa } \\
\hline Pemberian & Guru memulai kegiatan & Peserta didik dihadapkan \\
rangsangan & pembelajaran dengan & pada sesuatu yang \\
& mengajukan pertanyaan, anjuran & menimbulkan \\
& membaca buku, dan aktivitas & kebingungannya, \\
& belajar lainnya yang mengarah & kemudian dilanjutkan \\
& pada persiapan pemecahan & untuk tidak memberi \\
& masalah & generalisasi, agar timbul \\
& & keinginan untuk \\
\hline
\end{tabular}

220 | Mabasan, Vol. 13, No. 2, Desember 2019, hlm. 209-230 p-ISSN: 2085-9554, e-ISSN: 2621-2005 


\begin{tabular}{|c|c|c|}
\hline & & $\begin{array}{l}\text { menyelidiki sendiri. } \\
\text { - Stimulasi pada fase ini } \\
\text { berfungsi untuk } \\
\text { menyediakan kondisi } \\
\text { interaksi belajar yang } \\
\text { dapat mengembangkan } \\
\text { dan membantu peserta } \\
\text { didik dalam } \\
\text { mengeksplorasi bahan. }\end{array}$ \\
\hline $\begin{array}{l}\text { Pernyataan/identif } \\
\text { y-kasi masalah } \\
\text { (Problem } \\
\text { statement) }\end{array}$ & $\begin{array}{l}\text { Guru memberi kesempatan } \\
\text { kepada peserta didik untuk } \\
\text { mengidentifikasi sebanyak } \\
\text { mungkin agenda-agenda masalah } \\
\text { yang relevan dengan bahan } \\
\text { pelajaran, kemudian salah } \\
\text { satunya dipilih dan dirumuskan } \\
\text { dalam bentuk hipotesis (jawaban } \\
\text { sementara atas pertanyaan } \\
\text { masalah) }\end{array}$ & $\begin{array}{l}\text { Permasalahan yang dipilih } \\
\text { itu selanjutnya harus } \\
\text { dirumuskan dalam bentuk } \\
\text { pertanyaan, atau hipotesis, } \\
\text { yakni pernyataan sebagai } \\
\text { jawaban sementara atas } \\
\text { pertanyaan yang diajukan }\end{array}$ \\
\hline $\begin{array}{l}\text { Pengumpulan data } \\
\text { (data collection) }\end{array}$ & $\begin{array}{l}\text { Ketika eksplorasi berlangsung, } \\
\text { guru juga memberi kesempatan } \\
\text { kepada para peserta didik untuk } \\
\text { mengumpulkan informasi yang } \\
\text { relevan sebanyak-banyaknya } \\
\text { untuk membuktikan benar atau } \\
\text { tidaknya hipotesis }\end{array}$ & $\begin{array}{l}\text { Tahap ini berfungsi untuk } \\
\text { menjawab pertanyaan atau } \\
\text { membuktikan benar } \\
\text { tidaknya hipotesis. Dengan } \\
\text { demikian, peserta didik } \\
\text { diberi kesempatan untuk } \\
\text { mengumpulkan (Collection) } \\
\text { berbagai informasi yang } \\
\text { relevan, membaca literatur, } \\
\text { mengamati objek, } \\
\text { wawancara dengan nara } \\
\text { sumber, melakukan uji coba } \\
\text { sendiri dan sebagainya. }\end{array}$ \\
\hline $\begin{array}{l}\text { Pengolahan data } \\
\text { (Data processing) }\end{array}$ & $\begin{array}{l}\text { Guru melakukan bimbingan } \\
\text { pada saat peserta didik } \\
\text { melakukan pengolahan data }\end{array}$ & $\begin{array}{l}\text { Pengolahan data merupakan } \\
\text { kegiatan mengolah data dan } \\
\text { informasi, baik melalui } \\
\text { wawancara, observasi, dan } \\
\text { sebagainya, lalu ditafsirkan. } \\
\text { Semua informasi hasil } \\
\text { bacaan, wawancara, } \\
\text { observasi dan sebagainya } \\
\text { semuanya diolah, diacak, } \\
\text { diklasifikasikan, ditabulasi } \\
\text { bahkan bila perlu dihitung } \\
\text { dengan cara tertentu serta } \\
\text { ditafsirkan pada tingkat } \\
\text { kepercayaan tertentu. }\end{array}$ \\
\hline $\begin{array}{l}\text { Pembuktian } \\
\text { (verification) }\end{array}$ & $\begin{array}{l}\text { Verifikasi bertujuan agar proses } \\
\text { belajar akan berjalan dengan }\end{array}$ & $\begin{array}{l}\text { Peserta didik melakukan } \\
\text { pemeriksaan secara cermat }\end{array}$ \\
\hline
\end{tabular}




\begin{tabular}{|c|c|c|}
\hline & $\begin{array}{l}\text { baik dan kreatif jika guru } \\
\text { memberikan kesempatan kepada } \\
\text { peserta didik untuk menemukan } \\
\text { suatu konsep, teori, aturan atau } \\
\text { pemahaman melalui contoh- } \\
\text { contoh yang ia jumpai dalam } \\
\text { kehidupannya. }\end{array}$ & $\begin{array}{l}\text { untuk membuktikan benar } \\
\text { atau tidaknya hipotesis yang } \\
\text { ditetapkan tadi dengan } \\
\text { temuan alternatif, } \\
\text { dihubungkan dengan hasil } \\
\text { pengolahan data }\end{array}$ \\
\hline $\begin{array}{l}\text { Menarik } \\
\text { simpulan/generalis } \\
\text { asi } \\
\text { (Generalization) }\end{array}$ & $\begin{array}{l}\text { Menarik kesimpulan } \\
\text { proses menarik } \\
\text { kesimpulan yang dapat dijadikan } \\
\text { prinsip umum dan berlaku untuk } \\
\text { semua kejadian atau masalah } \\
\text { yang sama, dengan } \\
\text { memperhatikan hasil verifikasi }\end{array}$ & $\begin{array}{l}\text { Berdasarkan hasil verifikasi } \\
\text { maka dirumuskan prinsip- } \\
\text { prinsip yang mendasari } \\
\text { generalisasi. }\end{array}$ \\
\hline
\end{tabular}

Sumber: Ariyana dkk. (2018:29--31) 


\subsection{Langkah Penggunaan Metode Discovery Learning}

Menurut Sardiman dalam Malawi, Kadarwati dan Dayu (2019:105), pada saat mengaplikasikan metode discovery learning, guru dapat berperan sebagai pembimbing dengan memberikan kesempatan kepada siswa untuk belajar secara aktif. Guru harus dapat membimbing dan mengarahkan kegiatan belajar siswa sesuai dengan tujuan pembelajaran.

Ariani dan Aji Septiaji (2019:99) menjelaskan bahwa setiap cerita yang disampaikan baik lisan atau tulisan tidak hanya bersifat nyata melainkan dapat bersifat khayalan, rekaan, dan hasil imajinasi pikiran.

Adapun aktivitas yang pertama dilakukan oleh peserta didik adalah kegiatan mengidentifikasi unsur-unsur dan menceritakan kembali isi teks narasi (cerita imajinasi).

Tujuan aktivitas pembelajaran ini adalah sebagai berikut.

1. Siswa dapat menentukan unsur-unsur pada teks cerita imajinasi yang dibaca dan didengar.

2. Siswa dapat menceritakan kembali isi teks cerita imajinasi yang didengar dan dibaca secara lisan, tulis, dan visual.
Menurut Ariani dan Aji Septiaji (2019:100-102), langkah-langkah dalam pembelajaran discovey learning pada pembelajaran teks cerita fantasi dengan kompetensi dasar mengidentifikasi unsurunsur teks narasi (cerita fantasi) yang dibaca dan didengar dapat dijelaskan sebagai berikut.

\section{A. Pemberian Rangsangan (Stimulation)}

1. Siswa menyaksikan tayangan tentang cerita imajinasi berjudul Panci Ajaib pada laman berikut ini https://www.youtube.com/watch?v=iav $f g q 4 x Y$.

2. Peserta didik melakukan curah pendapat untuk menggali pengetahuan yang berkaitan dengan tayangan yang telah disaksikan.

3. Peserta didik merespons pertanyaanpertanyaan yang membangun konteks dan berkaitan dengan tayangan terhadap unsur-unsur cerita imajinasi.

a. Apakah sebelumnya mereka pernah menyaksikan tayangan seperti cerita imajinasi sebagaimana tersebut di atas.

b. Menurut pendapat mereka, apa yang dimaksud dengan cerita imajinasi itu.

c. Apa yang membedakan cerita imajinasi dengan cerita lainnya. 
B. Identifikasi Masalah (Problem Statement)

1. Setelah merespons pertanyaanpertanyaan yang terkait dengan unsur-unsur dalam cerita imajinasi, selanjutnya peserta didik membaca teks cerita imajinasi yang bertopik hal-hal bersifat ajaib yang dibagikan pendidik.

2. Peserta didik secara berkelompok menyusun pertanyaan terkait dengan isi teks cerita imajinasi untuk diceritakan kembali dengan memperhatikan unsur-unsurnya.

3. Pendidik melakukan pengamatan terhadap aktivitas peserta didik.

\section{Pengumpulan Data (Data Collection)}

1. Peserta didik mendata unsur-unsur cerita imajinasi sesuai dengan isi teks.

2. Peserta didik mengklasifikasikan data berdasarkan isi teks.

3. Peserta didik mengidentifikasi hasil yang sudah diklasifikasi sesuai dengan isi teks.

\section{Pengolahan Data (Data Processing)}

1. Peserta didik secara berkelompok mendiskusikan data klasifikasi dan identifikasi unsur-unsur cerita imajinasi sesuai dengan isi teks.
2. Peserta didik secara berkelompok membaca dan membandingkan unsur-unsur pada dua teks cerita imajinasi.

3. Peserta didik menyimpulkan isi dua teks cerita imajinasi.

\section{E. Pembuktian (Verification)}

1. Peserta didik melakukan kunjungan kerja ke kelompok lain. Satu orang anggota kelompok bertugas menjelaskan hasil diskusi dikelompok masing-masing.

2. Kelompok yang dikunjungi melakukan presentasi dan memberikan penjelasan hasil kerja kelompok. Peserta didik yang berkunjung memberikan respons dengan memberikan tanggapan dan pertanyaan untuk mendalami dan mengetahui kebenaran hasil identifikasi teks yang telah dibaca.

3. Peserta didik yang bertugas mempresentasikan dan memberikan penjelasan-penjelasan beserta alasan logis untuk membuktikan kebenaran hasil identifikasi yang telah didiskusikan di kelompok masing-masing.

4. Peserta didik yang berkunjung menuliskan catatan-catatan di kertas post it berupa penilaian, 
tanggapan, atau masukan terhadap hasil kerja kelompok lain dan menempelkannya pada plano hasil kerja kelompok tersebut.

5. Setiap kelompok menempelkan hasil diskusi pada tempat pajangan yang disediakan.

\section{$F$. Menarik Simpulan (Generalization)}

Guru dan siswa secara bersamasama menyimpulkan materi yang telah dipelajari denagn langkah-langkah sebagai berikut.

1. Peserta didik mengungkapkan kembali tentang unsur-unsur yang terdapat dalam teks yang telah dibaca.

2. Peserta didik menuliskan simpulan di "kartu simpul" yang telah disiapkan pendidik mengenai unsur-unsur yang telah diidentifikasi melalui kegiatan mendengarkan dan membaca.

3. Peserta didik menempelkan kartu simpul yang telah diisi pada kertas plano yang akan dipajangkan di dinding kelas.

4. Peserta didik dan pendidik secara bersama-sama menyimpulkan pembelajaran teks cerita imajinasi.

Selanjutnya menurut Ariani dan Aji Septiaji (2019:105), peserta didik diserahi tugas oleh guru untuk mengisi lembar kerja siswa dengan kompetensi dasar mengidentifikasi unsur-unsur dan menceritakan kembali isi teks cerita imajinasi.

Adapun tujuan dari pembelajaran tersebut adalah

1. Siswa dapat mengidentifikasi unsurunsur teks narasi (cerita imajinasi) yang dibaca dan didengar.

2. Siswa dapat menceritakan kembali isi teks narasi (cerita imajinasi) yang didengar dan dibaca secara lisan, tulis, dan visual.

Adapun petunjuk kerja dapat diterapkan adalah sebagai berikut.

1. Siswa diarahkan untuk membentuk kelompok yang terdiri atas 4 (empat) sampai 5 (lima) orang siswa.

2. Masing-masing peserta didik menyaksikan tayangan video dan membaca teks.

3. Setiap siswa mengidentifikasi unsurunsur teks cerita imajinasi.

4. Setiap peserta didik dalam satu kelompok menceritakan kembali teks cerita imajinasi secara berantai.

Selanjutnya peserta didik diarahkan untuk mengikuti instruksi guru sebagai berikut.

1. Peserta didik diperintahkan untuk membaca dengan saksama sebuah teks. Teks tersebut sebagaimana dalam 
Ariani dan Aji Septiaji (2019) dengan judul "Kerbau dan Sapi yang Bertukar Kulit”. Cerita tersebut dapat diunduh dari internet dengan laman: https://thegorbalsla.com/ceritadongeng.

2. Setelah siswa membaca teks cerita imajinasi dari laman tersebut di atas, dilanjutkan dengan menentukan unsur-unsurnya.

3. Setelah menentukan unsur-unsur dari teks di atas, siswa memperhatikan kedua teks berikutnya, kemudian, menjelaskannya.

3. Selanjutnya teks cerita imajinasi 1 dengan judul Aladin dan Lampu Ajaib yang dapat diunduh dari sumber: dongengceritarakyat.com.

4. Selanjutnya dipaparkan kembali sebuah teks cerita imajinasi 2 dengan judul "Tukang Sepatu dan Liliput" yang diunduh

dari

sumber:

dongengceritarakyat.com.

Setelah siswa membaca kedua teks di atas, maka mereka diharapkan dapat menjelaskan perbedaan unsur-unsurnya pada teks 1 dan teks 2 .

5. Setelah memahami teks cerita imajinasi di atas, siswa membentuk kelompok dengan beranggotakan 4 atau 5 orang, kemudian menceritakan kembali berdasarkan isi teks cerita imajinasi secara berantai.

6. Teks yang akan diceritakan kembali dipilih berdasarkan tiga teks di atas yaitu berjudul Kerbau dan Sapi yang Bertukar Kulit; Aladin dan Lampu Ajaib; dan Tukang Sepatu dan Liliput.

7. Pada saat satu kelompok tampil memaparkan hasil pekerjaannya, kelompok lain menilai dengan format berikut.

\begin{tabular}{|l|l|l|l|l|l|l|}
\hline \multirow{2}{*}{ No. } & \multicolumn{1}{|c|}{ Yang Diamati } & \multicolumn{4}{c|}{ Skor } & \multirow{2}{*}{ Skor } \\
\cline { 4 - 5 } & \multicolumn{1}{|c|}{1} & 2 & 3 & 4 & \\
\hline 1 & Kelancaran dalam penceritaan & & & & & \\
\hline 2 & $\begin{array}{l}\text { Ketepatan isi dengan cerita yang } \\
\text { disampaikan siswa }\end{array}$ & & & & \\
\hline 3 & Kejelasan intonasi dan lafal & & & & & \\
\hline 4 & Kekompakan kelompok & & & & & \\
\hline 5 & Kepercayaan diri & & & & & \\
\hline
\end{tabular}

Keterangan :

Skor 4 = Semua, anggota kelompok melakukan secara tepat

Skor 3 = sebagian besar, anggota kelompok melakukan secara tepat 
$\begin{aligned} \text { Skor } 2= & \text { tepat sebagian kecil, anggota } \\ & \text { kelompok melakukan secara } \\ & \text { tepat }\end{aligned}$

Skor 1 = Semua, anggota melakukan secara tidak tepat

\subsection{Hasil yang Dicapai}

Hasil yang dicapai saat penerapan model discovery learning pada pembelajaran teks narasi (cerita imajinasi) dapat digambarkan bahwa siswa terlihat aktif dalam proses pembelajaran, memahami materi pelajaran, menimbulkan rasa puas, dan melatih siswa belajar mandiri.

\subsection{Kelemahan Metode Discovery}

\section{Learning}

Dalam menerapkan model pembelajaran discovery learning, terdapat beberapa kendala yang sering dialami oleh pendidik. Hal ini disebabkan metode ini memiliki beberapa kelemahan sebagai berikut.

1. Metode ini menimbulkan asumsi bahwa ada kesiapan pikiran untuk belajar. Bagi peserta didik yang kurang cerdas, kemungkinan akan mengalami kesulitan pada aspek abstrak atau berfikir atau dalam mengungkapkan hubungan antara konsep-konsep yang tertulis atau lisan sehingga dapat menimbulkan frustasi pada peserta didik.

2. Metode ini tidak efisien untuk diterapkan pada siswa yang banyak karena membutuhkan waktu yang lama untuk membantu mereka menemukan teori dalam pemecahan masalah lainnya.

3. Harapan-harapan yang terkandung dalam metode discovery learning dapat buyar bila berhadapan dengan peserta didik dan pendidik yang telah terbiasa dengan cara-cara belajar yang lama.

4. Pengajaran model discovery lebih cocok untuk dikembangkan pada aspek yang memberikan pemahaman, sedangkan untuk pengembangan aspek konsep dan keterampilan serta emosi secara keseluruhan kurang mendapat perhatian.

5. Pada beberapa disiplin ilmu, sebagai contoh pada mata pelajaran Ilmu Pengetahuan Alam, terdapat kekurangan fasilitas untuk mengukur gagasan yang dikemukakan oleh para peserta didik.

6. Model ini tidak menyediakan kesempatan-kesempatan untuk berfikir yang akan ditemukan oleh peserta didik karena telah dipilih terlebih dahulu oleh pendidik.

Mabasan, Vol. 13, No. 2, Desember 2019, hlm. 209-230 


\subsection{Alternatif Pengembangan}

Beberapa alternatif pengembangan dalam implementasi model discovery learning yang bisa diterapkan.

1. Model discovery learning diterapkan dalam peningkatan keterampilan berbicara. Hal ini disebabkan keterampilan menulis dan berbicara memiliki kesamaan konsep dengan keterampilan produktif.

2. Model discovery learning dapat diimplementasikan pada mata pelajaran lainnya.

3. Model pembelajaran discovery learning bersifat universal, dapat diterapkan pada jenjang pendidikan Sekolah Dasar, Sekolah Menengah Pertama/sederajat, dan SMA serta SMK sederajat.

\section{Penutup}

Berdasarkan hasil pembahasan dapat disimpulkan bahwa untuk meningkatkan hasil belajar siswa, diperlukan strategi yang tepat. Salah satunya adalah penerapan strategi HOTS dengan model discovery learning. Langkah-langkah dalam penerapan model discovery learning dalam pembelajara teks narasi (cerita imajinasi) dimulai dari pemberian rangsangan, pernyataan/identifikasi masalah, pengumpulan data; pengolahan data, pembuktian, dan penarikan simpulan/generalisasi. Hasil pembelajaran dengan menggunakan model discovery learning pada materi pembelajaran teks narasi (cerita imajinasi) dapat meningkatkan keterampilan siswa dalam pembelajaran dimaksud. Penerapan model discovery learning memberikan hasil yang positif. Hal ini ditunjukkan dengan hasil belajar siswa yang berpola pikir kritis, berpendapat dan beralasan yang logis, kreatif, dapat memecahkan masalah, dan menulis esai argumentatif yang merefleksikan motivasi belajar.

Bagi guru mata pelajaran, penulis menyarankan agar dalam pembelajaran dengan menggunakan model discovery learning, hendaknya dapat memilih dan memilah situasi yang sesuai dengan karakteristik peserta didik. Hal ini dilakukan agar proses pembelajaran dapat berjalan dengan lancar dan tanpa hambatan. 


\section{Daftar Pustaka}

Ariani, Farida dan Aji Septiaji. (2019). Teks Deskripsi, Cerita Imajinasi, dan Prosedur. Jakarta: Direktorat Pembinaan Guru Pendidikan Dasar Direktorat Jenderal Guru Dan Tenaga Kependidikan Kementerian Pendidikan Dan Kebudayaan.

Ariyana, Yoki. Ari Pudjiastuti, Reisky Bestary, Zamroni. (2018). Buku Pegangan Pembelajaran Berorientasi pada Keterampilan Berpikir Tingkat Tinggi Program Peningkatan Kompetensi Pembelajaran Berbasis Zonasi. Jakarta: Direktorat Jenderal Guru dan Tenaga Kependidikan Kementerian Pendidikan dan Kebudayaan.

Ayu, Cheni Chaenida Madu. (2018). Discovery Learning Gerak Berirama. Gresik: Caremedia Communication.

Budiningsih, Asri C. (2005). Belajar dan Pembelajaran. Jakarta: Rhineka Cipta.

Fathoni, H. Abdurahmat. (2006). Metodologi Penelitian \& Teknik Penulisan Skripsi. Jakarta: Rineka Cipta.

Hestiyana. (2018). Bentuk Kesalahan Berbahasa pada Penulisan Iklan Media Luar Ruang di Kota Pelaihari. Dalam Jurnal Sirok Bastra: Jurnal Ilmiah Kebahasaan dan Kesastraan, Volume 6 Nomor (1), 81-92. Kantor Bahasa Kepulauan Bangka Belitung.

Hosnan, M. (2014). Pendekatan Saintifik dan Kontekstual dalam Pembelajaran Abad 21. Bogor: Ghalia Indonesia.

Kristianto, Dody. 2018. Eksistensialisme Tokoh Utama dalam Cerpen di
Joyoboyo Penyair Berteman Sunyi Karya Eko Darmoko dalam Jurnal Bebasan, volume 5 Nomor (1), 165174. Tangerang: Kantor Bahasa Banten.

Kurniasih, Imas dan Berlin Sani. (2014). Implementasi Kurikulum 2013 Konsep dan Penerapan. Surabaya: Kata Pena.

Malawi, dkk. (2019). Teori dan Aplikasi Pembelajaran Terpadu. Magetan: CV AE Media Grafika.

Mariyaningsih, Nining dan Mistina Hidayati. (2018). Bukan Kelas Biasa: Teori dan Praktik Berbagai Model dan Metode Pembelajaran menerapkan inovasi pembelajaran di kelas-kelas inspiratif. Surakarta: CV Kekata Group.

Moleong, Lexy J. (2009). Metodelogi Penelitian Kualitatif. Bandung: Remaja Rosdakarya.

Nazir, M. (2005). Metode Penelitian. Jakarta: Ghalia Indonesia.

Ruseffendi. (2006). Pengantar Kepada Membantu Guru Mengembangkan Kompetensinya dalam Pengajaran Matematika. Bandung: Tarsito.

Rohmadi, Muhammad. (2018). Strategi Dan Inovasi dalam Pembelajaran Bahasa dan Sastra Indonesia di Era Industri 4.0. dalam Prosiding Pertemuan Ilmiah Bahasa Dan Sastra Indonesia (PIBSI) Xl 2018, 27-40. Program Studi Pendidikan Bahasa Indonesia, FKIP Universitas Sebelas Maret Surakarta.

Sapari. (2019). Peningkatan Keterampilan Berbicara melalui Model Pembelajaran discovery learning pada Kelas VII semester I SMP Negeri 1 Metro Tahun Pelajaran 2018/2019. Didownload dari http://digilib.unila.ac.id/56998/2/TE

Mabasan, Vol. 13, No. 2, Desember 2019, hlm. 209-230 
SIS\%20TANPA\%20BAB\%20PEM BAHASAN.pdf 27 Agustus 2019 pkl. 15:36.

Sardiman, A.M. (2005). Interaksi dan Motivasi Belajar Mengajar. Jakarta: Rajawali Press.

Setiyaningsih, Ika., Meita Sandra Santhi. (2019). Pegangan Guru Bahasa Indonesia SMP/MTs kelas VII Semester I. Klaten: PT Penerbit Intan Pariwara.

Suhardi. (2019). Nilai Pendidikan Karakter Cerpen "Batu Lumut Kapas" Karya Gus Tf Sakai. Dalam Jurnal Genta Bahtera: Jurnal Ilmiah Kebahasaan dan Kesastraan Genta, Volume 5 Nomor (1), 35-45.
Pekanbaru: Kantor Bahasa Kepulauan Riau.

Suherman, Erman dkk. (2001). Strategi Pembelajaran Matematika Kontemporer. Bandung: Jica.

Widaningsih, Ida. (2019). Strategi dan Inovasi Pembelajaran Bahasa Indonesia di era revolusi Industri 4.0. Ponorogo: Uwais Inspirasi Indonesia. 